\title{
BCAT1 Gene
}

National Cancer Institute

\section{Source}

National Cancer Institute. BCAT1 Gene. NCI Thesaurus. Code C137954.

This gene is involved in amino acid catabolism. 